\title{
Relationships among adiponectin gene polymorphisms, proteinuria and increased blood pressure in the context of placental diseases
}

\author{
Bai Youpeng ${ }^{1,3}$, Xiong $\mathrm{Wei}^{1,3}$, Lin $\mathrm{Wei}^{1}$, Jia Jin ${ }^{1}$, Yu Haiyan ${ }^{1}$, Yang Yuan ${ }^{2}$ and Zhou Rong ${ }^{1}$
}

The etiology and pathogenesis of preeclampsia remain unclear. Little is known about the possible impact of adiponectin gene polymorphisms on the pathogenesis of preeclampsia. In this study, we analyzed the association of two adiponectin singlenucleotide polymorphisms (SNPs) with preeclampsia. One hundred eighty-eight Han Chinese pregnant women were enrolled (81 normal-term, 20 mild preeclampsia and 87 severe cases). Serum adiponectin level, and adiponectin exon 2 SNP +45T/G (rs2241766) genotype and intron 2 SNP +276G/T genotype ( $r$ 1501299) and their allele distributions were tested with enzyme-linked immunosorbent assay and PCR-restriction-fragment length polymorphism, respectively. There were no significant differences among the three groups $(P>0.05)$ in genotype distribution or allele frequencies of either SNP. Systolic pressure and 24-h urinary protein were lower in TT homozygotes than those in TG+GG patients at SNP +45T/G in the severe preeclamptic group $(P<0.05)$. Furthermore, blood pressure, serum adiponectin level and 24-h urinary protein were lower in GG homozygotes than those in $\mathrm{TG}+\mathrm{TT}$ patients at SNP $+276 \mathrm{G} / \mathrm{T}$ in the severe preeclamptic group $(P<0.05)$. The risk of high blood pressure $(\geqslant 160 / 110 \mathrm{~mm} \mathrm{Hg}$ ) and of high serum adiponectin in T-allele carriers at $+276 \mathrm{G} / \mathrm{T}$ in the severe preeclamptic group were 5.345 and 5.818 times higher, respectively, compared with GG patients. These data suggest that adiponectin $+45 \mathrm{~T} / \mathrm{G}$ and $+276 \mathrm{G} / \mathrm{T}$ polymorphisms are associated with important clinical manifestations of preeclampsia and that polymorphism $+276 \mathrm{G} / \mathrm{T}$ is associated with serum adiponectin level. Taken together, these findings suggest that adiponectin gene polymorphism is involved in the pathogenesis of preeclampsia.

Hypertension Research (2010) 33, 1066-1070; doi:10.1038/hr.2010.134; published online 22 July 2010

Keywords: adiponectin gene polymorphism; cardiovascular complications; preeclampsia

\section{INTRODUCTION}

Preeclampsia is a specific vascular disease that increases maternal and neonatal mortality and morbidity in pregnancy. ${ }^{1}$ The prevention and management of preeclampsia are difficult, especially in severe cases, because the etiology and pathogenesis of preeclampsia are unclear. Recent studies indicate that the interaction of adiponectin and its receptors might have a considerable role in the pathogenesis of preeclampsia $^{2-4}$ because of their important physiological functions, including anti-inflammatory, anti-atherosclerotic, vascular endothelial cell protection and insulin-sensitizing effects. ${ }^{5-8}$

Numerous single-nucleotide polymorphisms (SNPs) exist in the human adiponectin gene, located on chromosome $3 \mathrm{q} 27 .{ }^{9}$ SNPs of the adiponectin gene have been correlated with insulin resistance, type 2 diabetes, hypertension and cardiovascular diseases. ${ }^{10-16}$ Because endothelial dysfunction in the maternal blood vessels and insulin resistance are present in preeclamptic women and the role of adiponectin SNPs in the pathogenesis of preeclampsia has gone largely unexplored, we speculated that adiponectin SNPs might be associated with preeclampsia. Previous research revealed that only SNP276 in intron 2, but not SNP45 in exon 2, is associated with preeclampsia in Finnish women. ${ }^{17}$ Thus, in this study, we used the exon $2+45 \mathrm{~T} / \mathrm{G}$ (rs2241766) and the intron $2+276 \mathrm{G} / \mathrm{T}$ (rs1501299) SNPs as candidate gene markers to investigate the relationship between adiponectin polymorphism and preeclampsia in Chinese women.

\section{METHODS}

Subjects

One hundred eighty-eight Han Chinese pregnant women who visited the Department of Obstetrics and Gynecology, West China Second University Hospital, Sichuan University, from July 2007 to March 2009 were enrolled. One hundred seven women with preeclampsia ( 20 mild cases and 87 severe cases) according to the criteria of the International Society for the study of Hypertension in Pregnancy were included. Preeclampsia was defined as the development of blood pressure higher than $140 / 90 \mathrm{~mm} \mathrm{Hg}$ on two separate occasions $6 \mathrm{~h}$ apart or a single recording of a diastolic pressure of $110 \mathrm{~mm} \mathrm{Hg}$ in association with proteinuria $\geqslant 1$ by dipstick testing or proteinuria $\geqslant 300 \mathrm{mg}$

${ }^{1}$ Department of Obstetrics and Gynecology, West China Second University Hospital, Sichuan University, Chengdu, PR China and ${ }^{2}$ Department of Medical Genetics, West China Hospital, Sichuan University, Chengdu, PR China

${ }^{3}$ These authors contributed equally to this work.

Correspondence: Professor Z Rong, Department of Obstetrics and Gynecology, West China Second University Hospital, Sichuan University, Chengdu 610041, PR China.

E-mail: zhourong_hx@scu.edu.cn

Received 15 January 2010; revised 23 May 2010; accepted 24 May 2010; published online 22 July 2010 
per $24 \mathrm{~h}$. Subjects were devoid of hemolysis, elevated liver enzymes and low platelet count (HELLP syndrome). In addition, a total of 81 normal-term pregnant women were selected as a normal control group during the same period. The study was approved by the Institutional Ethics Committee of West China Second University Hospital, Sichuan University. All patients provided written informed consent.

Information on demographic characteristics of the normal, mild preeclamptic and severe preeclamptic group was recorded. Gestational age was based on the last menstrual period and/or was confirmed by ultrasound examination conducted early in the pregnancy. Pre-pregnancy body mass index was calculated as weight in kilograms divided by height in meters squared $\left(\mathrm{kg} \mathrm{m}^{-2}\right)$. Exclusion criteria included multiple pregnancy, diabetes, heart diseases, chronic hypertension, fetal malformation and chronic nephritis.

\section{Blood sample collection}

We collected patients' blood samples from cubital veins and transferred them to two tubes. One tube was stored at $-80^{\circ} \mathrm{C}$ to measure adiponectin levels with an ELISA kit (Phoenix Biotech, Beijing, China) according to the manufacturer's instructions. The inter-assay and intra-assay coefficients of variation were $<10 \%$ and $<15 \%$, respectively. The lower limit of sensitivity was $0.24 \mathrm{ng} \mathrm{ml}^{-1}$. Another tube was mixed with EDTA anticoagulant. After low-speed centrifugation, the precipitated blood cells were stored at $-20^{\circ} \mathrm{C}$ for genomic DNA extraction with a centrifugal column (Tiangen Biotech, Beijing, China).

\section{PCR}

The genomic DNA was isolated from blood cells. Previously published PCR primers were used: ${ }^{18}$ forward primer $5^{\prime}$-CTGAGATGGACGGAGTCCTTT-3', reverse primer $5^{\prime}$-CCAAATCACTTCAGGTTGCTT-3'. A $450 \mathrm{bp}$ specific PCR

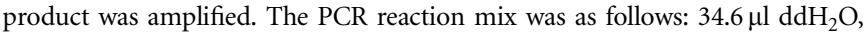
$5.0 \mu \mathrm{l} 10 \times$ PCR buffer, $4.0 \mu \mathrm{l} \mathrm{dNTP}(2.5 \mathrm{~mm}), 3.0 \mu \mathrm{Mg}^{2+}(25 \mathrm{~mm}), 0.4 \mu \mathrm{l} \mathrm{Taq}$ DNA polymerase $\left(5 \mathrm{U}^{-1} \mathrm{l}^{-1}\right)$ (Tiangen Biotech), $1.0 \mu \mathrm{l}$ forward primer $\left(10 \mathrm{pmol} \mathrm{l}^{-1}\right), 1.0 \mu \mathrm{l}$ reverse primer $\left(10 \mathrm{pmol} \mu \mathrm{l}^{-1}\right), 1.0 \mu \mathrm{l}$ DNA template (total volume $50 \mu \mathrm{l}$ ). The PCR cycling conditions included an initial denaturation at $94{ }^{\circ} \mathrm{C}$ for $5 \mathrm{~min}$ followed by 35 cycles at $94^{\circ} \mathrm{C}$ for $30 \mathrm{~s}, 58.7^{\circ} \mathrm{C}$ for $30 \mathrm{~s}$ and $72{ }^{\circ} \mathrm{C}$ for $1.0 \mathrm{~min}$. We terminated the reaction at $18^{\circ} \mathrm{C}$ and stored the PCR products at $4{ }^{\circ} \mathrm{C}$. Agarose gel (1.5\%) electrophoresis was used to detect PCR products.

\section{Restriction-fragment length polymorphism analysis}

The PCR products containing $+45 \mathrm{~T} / \mathrm{G}$ and $+276 \mathrm{G} / \mathrm{T}$ were digested successively by restriction endonucleases SmaI and BsmI (New England Biolabs, Beijing, China) at 25 and $65^{\circ} \mathrm{C}$, respectively, for $16 \mathrm{~h}$. The digestion included $5 \mu \mathrm{l} \mathrm{PCR}$

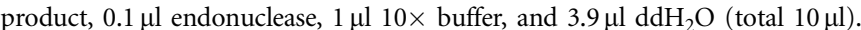
For genotype analysis, we ran the endonuclease-digested products in a $3 \%$ agarose gel at $100 \mathrm{~V}$ for $30 \mathrm{~min}$. The results were inspected and photographed under the ultraviolet lamp of a gel imaging system (Chemi doc XRS, no. Universal Hood11, Hercules, CA, USA).

The G-allele (CCCGGG) of the adiponectin $+45 \mathrm{~T} / \mathrm{G}$ SNP was recognized by $S m a I$ and digested into two fragments of 315 and $141 \mathrm{bp}$. After electrophoresis, DNA with genotype TT appeared as a band of $456 \mathrm{bp}$, genotype TG as three bands of 456, 315, and $141 \mathrm{bp}$ and genotype GG as two bands of 315 and 141 bp (Figure 1). The G-allele (GAATGC) of SNP $+276 \mathrm{G} / \mathrm{T}$ was recognized by $B s m I$. The G-allele was enzymatically digested into two fragments of 371 and $85 \mathrm{bp}$. After electrophoresis, genotype TT appeared as a 456-bp band, genotype TG as three bands of 456, 371, and $85 \mathrm{bp}$ and genotype GG as two bands of 371 and 85 bp (Figure 2).

\section{Statistical analysis}

The polymorphism allele frequencies were consistent with Hardy-Weinberg equilibrium. The genotype distribution was analyzed by the $\chi^{2}$-test. The measurement data are expressed as means \pm s.d. Differences between groups were evaluated using one-way analysis of variance followed by the MannWhitney $U$-test and paired or unpaired $t$-test. Correlation analysis was assessed by logistic single-factor analysis, and linkage disequilibrium was analyzed by SHEsis on-line analysis software. A value of $P<0.05$ was considered statistically significant.

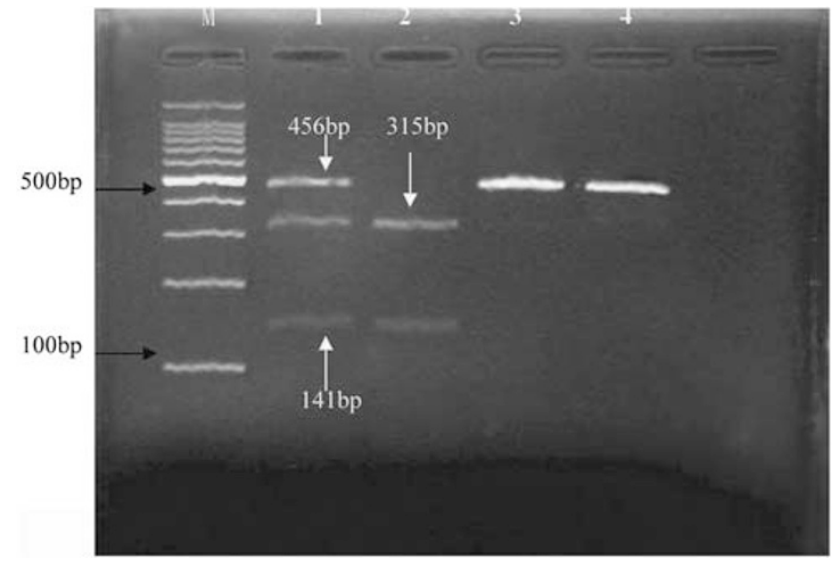

Figure 1 Agarose gel electrophoresis of endonuclease-digested PCR products containing the adiponectin +45T/G SNP. M: DNA marker; 1 : TG genotype; 2: GG genotype; 3: TT genotype; 4: control.

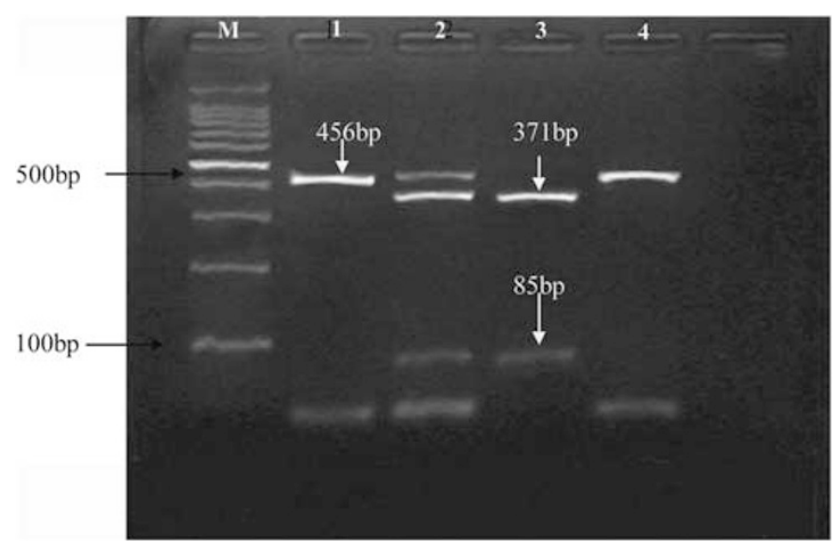

Figure 2 Agarose gel electrophoresis of endonuclease-digested PCR products containing the adiponectin $+276 \mathrm{G} / \mathrm{T}$ SNP. M: DNA marker; 1 : TT genotype; 2: TG genotype; 3: GG genotype; 4: control.

\section{RESULTS}

Demographic characteristics of the three groups

The demographic and clinical characteristics of pregnant women are shown in Table 1 . There were no statistically significant differences among normal, mild preeclamptic and severe preeclamptic patients in maternal age, pre-pregnancy body mass index, gestational age at blood collection or proportions of primiparas, smokers and unmarried women (all $P>0.05$, Table 1).

\section{Distributions of the adiponectin $+45 \mathrm{~T} / \mathrm{G}$ and $+276 \mathrm{G} / \mathrm{T}$} polymorphisms in the three groups

There were no significant differences in genotype distribution or allele frequencies of the $+45 \mathrm{~T} / \mathrm{G}$ or $+276 \mathrm{G} / \mathrm{T}$ SNP among the three groups $(P>0.05$, Table 2).

Comparison of clinical manifestations and serum adiponectin level associated with different $+45 \mathrm{~T} / \mathrm{G}$ genotypes in the three groups In the severe preeclamptic group, systolic pressure and 24-h urinary protein were lower in TT homozygotes than those in G-allele carriers (TG+GG) at $+45 \mathrm{~T} / \mathrm{G}$. However, neither the mild preeclamptic nor the normal patients displayed any difference in systolic pressure or 24-h urinary protein between these two genotype groups. In each clinical 
Table 1 Demorgraphic characteristics of the three groups

\begin{tabular}{lccc}
\hline & $\begin{array}{c}\text { Mild pre- } \\
\text { eclampsia }\end{array}$ & $\begin{array}{c}\text { Severe pre- } \\
\text { eclampsia }\end{array}$ & Normal \\
\hline$n$ & 20 & 87 & 81 \\
Years & $30.9 \pm 5.8$ & $30.9 \pm 6.0$ & $30.0 \pm 4.5$ \\
Pre-pregnancy body mass index & $22.5 \pm 2.9$ & $21.6 \pm 2.4$ & $20.1 \pm 1.8$ \\
(kg m $^{-2}$ ) & & & \\
Gestational weeks at collecting blood & $35.4 \pm 1.2$ & $34.9 \pm 1.6$ & $35.4 \pm 1.2$ \\
Primiparas (\%) & $16(80.0)$ & $70(80.5)$ & $66(81.5)$ \\
Smoking (\%) & $0(0)$ & $0(0)$ & $0(0)$ \\
Unmarried (\%) & $0(0)$ & $0(0)$ & $0(0)$ \\
\hline
\end{tabular}

Table 2 The distribution and allele frequencies of adiponectin gene at $+45 \mathrm{~T} / \mathrm{G}$ and $+276 \mathrm{G} / \mathrm{T}$

\begin{tabular}{|c|c|c|c|}
\hline & $\begin{array}{l}\text { Mild preeclampsia } \\
\qquad(\mathrm{n}=20)\end{array}$ & $\begin{array}{l}\text { Severe preeclampsia } \\
\qquad(\mathrm{n}=87)\end{array}$ & $\begin{array}{l}\text { Normal } \\
(\mathrm{n}=81)\end{array}$ \\
\hline \multicolumn{4}{|c|}{ +45T/G Gene types (\%) } \\
\hline TT & $0.75(15)$ & $0.68(59)$ & $0.65(53)$ \\
\hline TG & $0.2(4)$ & $0.25(22)$ & $0.33(27)$ \\
\hline GG & $0.05(1)$ & $0.07(6)$ & $0.01(1)$ \\
\hline $\mathrm{TG}+\mathrm{GG}$ & $0.25(5)$ & $0.32(28)$ & $0.35(28)$ \\
\hline \multicolumn{4}{|c|}{ Allele frequencies (\%) } \\
\hline $\mathrm{T}$ & $0.85(34)$ & $0.81(140)$ & $0.82(133)$ \\
\hline $\mathrm{G}$ & $0.15(6)$ & $0.20(34)$ & $0.18(29)$ \\
\hline \multicolumn{4}{|c|}{ +276G/T Gene types (\%) } \\
\hline GG & $0.2(4)$ & $0.17(15)$ & $0.24(19)$ \\
\hline TG & $0.6(12)$ & $0.55(48)$ & $0.61(49)$ \\
\hline TT & $0.2(4)$ & $0.28(24)$ & $0.16(13)$ \\
\hline $\mathrm{TG}+\mathrm{TT}$ & $0.8(16)$ & $0.83(72)$ & $0.77(62)$ \\
\hline \multicolumn{4}{|c|}{ Allele frequencies (\%) } \\
\hline $\mathrm{T}$ & $0.5(20)$ & $0.55(96)$ & $0.54(87)$ \\
\hline $\mathrm{G}$ & $0.5(20)$ & $0.45(78)$ & $0.46(75)$ \\
\hline
\end{tabular}

group, no significant difference in serum adiponectin level between genotype TT and TG+GG was observed (Table 3).

Comparison of clinical manifestations and serum adiponectin level associated with different $+276 \mathrm{G} / \mathrm{T}$ genotypes in the three groups In the severe preeclamptic group, systolic pressure, diastolic pressure, 24-h urinary protein and serum adiponectin level were lower in GG homozygotes than those in T-allele carriers $(\mathrm{TG}+\mathrm{TT})$ at $+276 \mathrm{G} / \mathrm{T}$. In addition, systolic pressure and diastolic pressure were lower in GG than those in TG+TT patients in the normal group (Table 4).

Correlations of the $+45 \mathrm{~T} / \mathrm{G}$ and $+276 \mathrm{G} / \mathrm{T}$ SNPs and clinical manifestations with serum adiponectin level in severe preeclampsia In the severe preeclamptic group, the risk of elevated 24-h urinary protein $(\geqslant 2 \mathrm{~g}$ per $24 \mathrm{~h}$ ) in G-allele carriers was 3.167 (OR) times higher than that in TT homozygotes at $+45 \mathrm{~T} / \mathrm{G}$. However, at $+276 \mathrm{G} /$ $\mathrm{T}$, the risk of elevated 24 -h urinary protein $(\geqslant 2 \mathrm{~g}$ per $24 \mathrm{~h}$ ) in T-allele carriers was 5.654 times higher than that in GG homozygotes; the risk of elevated blood pressure ( $\geqslant 160 / 110 \mathrm{~mm} \mathrm{Hg}$ ) in T-allele carriers was 5.345 times higher than that in GG homozygotes; and the risk of elevated serum adiponectin in T-allele carriers was 5.818 times higher than that in GG homozygotes.

\section{DISCUSSION}

Vascular endothelial cells secrete a variety of vasoactive substances to maintain the homeostasis of the vascular system during normal pregnancy by controlling local or systemic vascular tone, participating in the intravascular hemostatic process and regulating vascular smooth muscle cell proliferation. ${ }^{19,20}$ However, in patients with preeclampsia, damage to endothelial cells is evident in the early stages of pregnancy. ${ }^{21,22}$ During the pregnancy, more vasoconstrictors (such as endothelin and angiotensin) are synthesized and secreted in these patients, whereas vasodilators (such as NO, PGI2 and PGE) are reduced. This process eventually leads to increased vascular permeability and blood concentration. In the clinic, the patients may show a series of manifestations, such as high blood pressure and proteinuria. $^{23,24}$

As a vasoactive substance reacting with its specific receptors (AdipoR1 and AdipoR2), adiponectin has important physiological roles, such as protecting vascular endothelial cells, increasing insulin sensitivity, inhibiting inflammation and inhibiting atherosclerosis.

Table 3 Clinical manifestations and serum adiponectin levels of different genotypes of adiponectin gene at $+45 T / G$ in the three groups

\begin{tabular}{|c|c|c|c|c|c|c|}
\hline \multirow[b]{2}{*}{ Manifestations } & \multicolumn{2}{|c|}{ Severe } & \multicolumn{2}{|c|}{ Mild } & \multicolumn{2}{|c|}{ Normal } \\
\hline & $T T(\mathrm{n}=59)$ & $T G+G G(\mathrm{n}=28)$ & $T T \mathrm{n}(=15)$ & $T G+G G \mathrm{n}(=5)$ & $T T(\mathrm{n}=53)$ & $T G+G G(\mathrm{n}=28)$ \\
\hline Delivery weeks & $34.4 \pm 3.3$ & $34.8 \pm 2.7$ & $36.6 \pm 2.8$ & $36.5 \pm 3.7$ & $38.0 \pm 2.4$ & $39.6 \pm 0.5$ \\
\hline $\mathrm{SBP}(\mathrm{mm} \mathrm{Hg})$ & $146.0 \pm 14.8$ & $154.4 \pm 11.6^{*}$ & $138.2 \pm 14.1$ & $149.8 \pm 22.3$ & $114.9 \pm 12.2$ & $115.1 \pm 11.0$ \\
\hline $\mathrm{DBP}(\mathrm{mm} \mathrm{Hg})$ & $94.2 \pm 11.9$ & $93.7 \pm 15.6$ & $89.1 \pm 11.1$ & $88.2 \pm 12.3$ & $71.3 \pm 9.2$ & $72.7 \pm 10.1$ \\
\hline Serum blood urea $\left(\mathrm{mmol} \mathrm{I}^{-1}\right)$ & $5.3 \pm 2.3$ & $5.4 \pm 2.5$ & $3.9 \pm 1.9$ & $5.5 \pm 3.4$ & $3.4 \pm 1.1$ & $3.2 \pm 1.4$ \\
\hline Serum creatinine $\left(\mu \mathrm{mol} \mathrm{I}^{-1}\right)$ & $65.6 \pm 21.3$ & $69.2 \pm 26.9$ & $52.9 \pm 28.4$ & $58.0 \pm 18.4$ & $51.2 \pm 20.0$ & $38.8 \pm 13.0$ \\
\hline Serum albumin $\left(\mathrm{gl}^{-1}\right)$ & $28.3 \pm 5.5$ & $27.7 \pm 5.4$ & $32.0 \pm 5.4$ & $30.8 \pm 2.7$ & $34.3 \pm 6.7$ & $34.3 \pm 3.3$ \\
\hline Birth weight (g) & $2112.8 \pm 724.8$ & $2096.7 \pm 731.0$ & $2637.0 \pm 761.8$ & $3137.0 \pm 1156.4$ & $3298.9 \pm 581.9$ & $3221.7 \pm 236.9$ \\
\hline Birth length $(\mathrm{cm})$ & $42.0 \pm 4.8$ & $42.4 \pm 4.1$ & $45.1 \pm 4.1$ & $45.4 \pm 7.3$ & $49.3 \pm 2.3$ & $49.3 \pm 0.6$ \\
\hline Urine protein (g per $24 \mathrm{~h}$ ) & $3.5 \pm 2.0$ & $4.8 \pm 2.6^{* *}$ & $1.6 \pm 0.4$ & $1.4 \pm 0.6$ & - & - \\
\hline Serum adiponectin $\left(\mathrm{ng} \mathrm{ml}^{-1}\right)$ & $4963.4 \pm 2871.7$ & $4387.7 \pm 2460.2$ & $5190.4 \pm 102.7$ & $3830.7 \pm 2927.3$ & $3747.5 \pm 1182.4$ & $4152.7 \pm 1221.4$ \\
\hline
\end{tabular}

Abbreviations: DBP, diastolic blood pressure at collecting samples; SBP, systolic blood pressure at collecting samples. 
Table 4 Clinical manifestations and serum adiponectin levels of different genotypes of adiponectin gene at $+276 \mathrm{G} / \mathrm{T}$ in the three groups

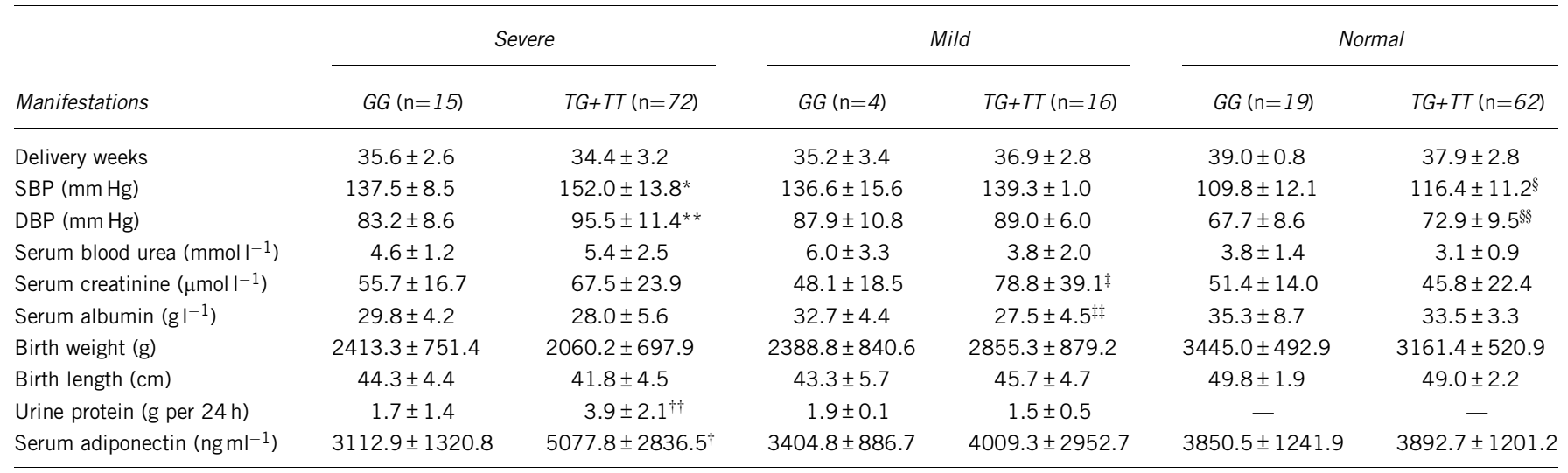

Abbreviations: DBP, diastolic blood pressure at collecting samples; SBP, systolic blood pressure at collecting samples.

${ }^{*} P=0.002$ when compared with $\mathrm{GG}$ genotypes in severe preeclamptic group.

$* * P=0.005$ when compared with GG genotypes in severe preeclamptic group.

$\uparrow P=0.003$ when compared with $G G$ genotypes in severe preeclamptic group.

$P=0.046$ when compared with $G G$ genotypes in severe preeclamptic group.

$\ddagger P=0.03$ when compared with GG genotypes in mild preeclamptic group.

$\ddagger P=0.050$ when compared with GG genotypes in mild preeclamptic group.

$\S P=0.032$ when compared with GG genotypes in normal group.

$\$ \$ P=0.037$ when compared with GG genotypes in normal group.

By measuring plasma adiponectin in 1842 pregnant women in early pregnancy and tracking the outcomes of their pregnancies, D'Anna et $a l^{4}$ found that plasma adiponectin in patients with preeclampsia was lower than in pregnancy-induced hypertension patients and normal patients. Ramsay et al. ${ }^{25,26}$ also found that plasma adiponectin was significantly higher in preeclampsia compared with normal controls, although the adiponectin level was unrelated to adiponectin mRNA expression in the placenta. Ramsay et al. ${ }^{25}$ further suggested that adiponectin accumulation may be due to the increased synthesis following enhanced nonspecific lipolytic effects or increased use of fat, instead of excretion of it. This result suggested that the elevation of adiponectin was a physiological response to avoid damage to endothelial cells. Our preliminary study also indicated that plasma adiponectin in preeclamptic patients was significantly lower than in normal pregnant women. ${ }^{2}$ Although the studies about serum adiponectin level in preeclampsia and normal pregnancy are not consistent, significant differences have been seen between normal pregnancies and preeclampsia cases. This finding suggested to us that adiponectin could regulate vascular endothelial cell function during normal pregnancy and might be involved in the pathogenesis of preeclampsia.

The human adiponectin gene is located on chromosome $3 q 27$ and has a total length of about $17 \mathrm{~kb}$, including three exons and two introns. The $+276 \mathrm{G} / \mathrm{T}$ SNP in the adiponectin gene has been associated with higher body mass index $(P<0.01)$, plasma insulin $(P<0.02)$ and HOMA(IR) $(P<0.02) .{ }^{13}$ Compared with a normal glucose tolerance group, type 2 diabetes patients have been found to include more $\mathrm{TG}+\mathrm{GG}$ genotypes at $+45 \mathrm{~T} / \mathrm{G}$, and type 2 diabetes patients carrying the G-allele had a lower insulin sensitivity index and higher insulin resistance index. ${ }^{27}$ The adiponectin $+276 \mathrm{G} / \mathrm{T}$ SNP has been significantly correlated with the incidence of coronary heart diseases. ${ }^{15}$ Moreover, homozygous individuals have a higher risk of coronary heart diseases. ${ }^{28}$ In addition, one study demonstrated that plasma adiponectin concentration was markedly lower in TC genotype carriers at the adiponectin SNP $164 \mathrm{I} / \mathrm{T}$, and most of them had high blood pressure. ${ }^{29}$ These observations suggest that adiponectin gene polymorphism is closely linked to vascular diseases. Another study in Denmark found that at $+276 \mathrm{G} / \mathrm{T}$, a TT genotype reduced the incidence of preeclampsia compared with TG+GG. In addition, differences in genotype distribution and allele frequency at this SNP between the two groups were significant; for the exon $2+45 \mathrm{~T} / \mathrm{G}$, there were no significant differences in genotype distributions or allele frequencies between the two groups. ${ }^{17}$ Recently, another study in Czech Caucasians reported that although no significant associations were detected between the adiponectin T94G SNP and any of the biomarkers related to preeclampsia, such as gestational hypertension and proteinuria, the T94G polymorphism was significantly associated with a low birth weight in preeclamptic pregnancies. ${ }^{30}$

In our study, we compared the adiponectin $+45 \mathrm{~T} / \mathrm{G}$ and $+276 \mathrm{G} / \mathrm{T}$ polymorphisms between Han Chinese pregnant women with and without preeclampsia. We found no significant difference in $+45 \mathrm{~T} / \mathrm{G}$ or $+276 \mathrm{G} / \mathrm{T}$ genotype distribution or allele frequencies among mild preeclamptic, severe preeclamptic and normal patients $(P>0.05)$. We speculate that this result might be related to differences in adiponectin gene polymorphism in different populations and also to the relatively small study population. However, our data are partially in agreement with other studies demonstrating that $+45 \mathrm{~T} / \mathrm{G}$ and $+276 \mathrm{G} / \mathrm{T}$ are associated with many important clinical manifestations, such as blood pressure and 24-h urinary protein, in patients with preeclampsia. These data suggest that the $+45 \mathrm{~T} / \mathrm{G}$ and $+276 \mathrm{G} / \mathrm{T}$ polymorphisms may be involved in preeclampsia.

Interestingly, we found that in the normal group, systolic pressure and diastolic pressure (and, in the mild preeclamptic group, serum creatinine and albumin) showed significant differences between GG homozygotes and TG+TT patients at $+276 \mathrm{G} / \mathrm{T}$. We speculate that these results might be due to the small sample size of our study. Further investigation is needed.

Previous reports have shown that in type 2 diabetic patients, the G-allele of $+276 \mathrm{G} / \mathrm{T}$ is associated with low adiponectin level. ${ }^{31} \mathrm{An}$ investigation of the relationship between adiponectin SNPs $-11377 \mathrm{C} / \mathrm{G}$, $-4041 \mathrm{~A} / \mathrm{C},+45 \mathrm{~T} / \mathrm{G}$, and $+276 \mathrm{G} / \mathrm{T}$ and serum adiponectin level also found that only $+276 \mathrm{G} / \mathrm{T}$ was correlated with serum adiponectin level and that TT homozygotes had higher adiponectin levels. ${ }^{32}$ In accordance with these findings, we discovered that in the severe preeclamptic group, only the $+276 \mathrm{G} / \mathrm{T}$, but not the $+45 \mathrm{~T} / \mathrm{G}$, polymorphism was associated with elevated serum adiponectin. 
In conclusion, this cross-sectional study shows that adiponectin gene $+45 \mathrm{~T} / \mathrm{G}$ and $+276 \mathrm{G} / \mathrm{T}$ polymorphisms were associated with important clinical manifestations of preeclampsia; the $+276 \mathrm{G} / \mathrm{T}$ polymorphism was also closely associated with elevated serum adiponectin. Our results indicate that adiponectin gene polymorphism might be related to preeclampsia. Because this was only a smallscale cross-sectional study of adiponectin gene polymorphism in Han Chinese preeclamptic patients, the relationship between adiponectin gene polymorphism and preeclampsia should be validated in multicenter, large-scale, prospective studies.

\section{CONFLICT OF INTEREST}

The authors declare no conflict of interest.

\section{ACKNOWLEDGEMENTS}

Grants from Ministry of Education of China (20070610102) and the Office of Science \& Technology of Sichuan province (2009SZ0149) are gratefully acknowledged.

1 Yücesoy G, Ozkan S, Bodur H, Tan T, Calișkan E, Vural B, Corakçi A. Maternal and perinatal outcome in pregnancies complicated with hypertensive disorder of pregnancy: a seven year experience of a tertiary care center. Arch Gynecol Obstet 2005; 273: 43-49.

2 Herse F, Bai Youpeng, Staff AC, Yong-Meid J, Dechend R, Zhou Rong. Circulating and uteroplacental adipocytokine concentrations in preeclampsia. Reprod Sci 2009; 16: 584-590.

3 Tie Weiwei, Yu Haiyan, Chen Juan, Wang Xiaodong, Chen Weibo, Zhou Rong. Expression of adiponectin receptors in placenta and their correlation with preeclampsia. Reprod Sci 2009; 16: 676-684.

4 D'Anna R, Baviera G, Corrado F, Giordano D, Di Benedetto A, Jasonni VM. Plasma adiponectin concentration in early pregnancy and subsequent risk of hypertensive disorders. Obstet Gynecol 2005; 106: 340-344.

5 Haluzík M, Parízková J, Haluzík MM. Adiponectin and its role in the obesity-induced insulin resistance and related complications. Physiol Res 2004; 53: 123-129.

6 Jalovaara K, Santaniemi M, Timonen M, Jokelainen J, Kesäniemi YA, Ukkola O, Keinänen-Kiukaanniemi S, Rajala U. Low serum adiponectin level as a predictor of impaired glucose regulation and type 2 diabetes mellitus in a middle-aged Finnish population. Metabolism 2008; 57: 1130-1134.

7 Piestrzeniewicz K, Luczak K, Komorowski J, Maciejewski M, Piechowiak M, JankiewiczWika J, Goch JH. Obesity and adiponectin in acute myocardial infarction. Cardiol J 2007; 14: 29-36.

8 Matsuda M, Shimomura I, Sata M, Arita Y, Nishida M, Maeda N, Kumada M, Okamoto Y, Nagaretani H, Nishizawa H, Kishida K, Komuro R, Ouchi N, Kihara S, Nagai R, Funahashi T, Matsuzawa Y. Role of adiponectin in preventing vascular stenosis. The missing link of adipo-vascular axis. J Biol Chem 2002; 277: 37487-37491.

9 Ukkola O, Ravussin E, Jacobson P, Sjöström L, Bouchard C. Mutations in the adiponectin gene in lean and obese subjects from the Swedish obese subjects cohort. Metabolism 2003; 52: 881-884.

10 Vionnet N, Hani EH, Dupont S, Gallina S, Francke S, Dotte S, De Matos F, Durand E, Leprêtre F, Lecoeur C, Gallina P, Zekiri L, Dina C, Froguel P. Genomewide search for type 2 diabetes-susceptibility genes in French whites: evidence for a novel susceptibility locus for early-onset diabetes on chromosome 3q27-qter and independent replication of a type 2 diabetes locus on chromosome 1q21-q24. Am J Hum Genet 2000; 67: 1470-1480.

11 Francke S, Manraj M, Lacquemant C, Lecoeur C, Leprêtre F, Passa P, Hebe A, Corset L, Yan SL, Lahmidi S, Jankee S, Gunness TK, Ramjuttun US, Balgobin V, Dina C, Froguel P. A genome wide scan for coronary heart disease suggests in Indo-Mauritians a susceptibility locus on chromosome $16 \mathrm{p} 13$ and replicates linkage with the metabolic syndrome on 3q27. Hum Mol Genet 2001; 10: 2751-2765.

12 Gu HF, Abulaiti A, Ostenson CG, Humphreys K, Wahlestedt C, Brookes AJ, Efendic S. Single nucleotide polymorphisms in the proximal promoter region of the adiponectin (APM-1) gene are associated with type 2 diabetes in Swedish Caucasians. Diabetes 2004; 53(Suppl 1): S31-S35.

13 Filippi E, Sentinelli F, Trischitta V, Romeo S, Arca M, Leonetti F, Di Mario U, Baroni MG. Association of the human adiponectin gene and insulin resistance. Eur $J$ Hum Genet 2004; 12: 199-205.

14 Pischon T, Pai JK, Manson JE, Hu FB, Rexrode KM, Hunter D, Rimm EB. Single nucleotide polymorphisms at the adiponectin locus and risk of coronary heart disease in men and women. Obesity (Silver Spring) 2007; 15: 2051-2060.

15 Filippi E, Sentinelli F, Romeo S, Arca M, Berni A, Tiberti C, Verrienti A, Fanelli M, Fallarino M, Sorropago G, Baroni MG. The adiponectin gene SNP+276G $>$ T associates with early-onset coronary artery disease and with lower levels of adiponectin in younger coronary artery disease patients (age $<$ or $=50$ years). J Mol Med 2005; 83: 711-719.

16 Jeng JR. Plasma adiponectin, T94G gene polymorphism and PAI-1 in patients with and without hypertension. Cardiology 2007; 107: 30-37.

17 Saarela T, Hiltunen M, Helisalmi S, Heinonen S, Laakso M. Adiponectin gene haplotype is associated with preeclampsia. Genet Testing 2006; 10: 35-39.

18 Dong Yan, Li Guo, Luo Tian-hong, Wu Gang, Huang Wei, Luo Min. Relationship between adiponectin gene polymorphisms and type 2 diabetes. Acad J Shanghai Second Med Univ 2004; 24: 1001-1003.

19 Martins e Silva J, Saldanha C. Arterial endothelium and atherothrombogenesis. I-Intact endothelium in vascular and blood homeostasis. Rev Port Cardiol 2006; 25: 1061-1083.

20 Ahmed A, Cudmore MJ. Can the biology of VEGF and haem oxygenases help solve preeclampsia? Biochem Soc Trans 2009; 37(part 6): 1237-1242.

21 Scalera F, Dittrich R, Beckmann MW, Beinder E. Effect of endothelin-1 on intracellular glutathione and lipid peroxide availability and on the secretion of vasoactive substances by human umbilical vein endothelial cells. Eur J Clin Invest 2002; 32: 556-562.

22 Canbakan B, Keven K, Tutkak H, Danisman N, Ergun I, Nergizoglu G. Circulating endothelial cells in preeclampsia. J Hum Hypertens 2007; 21: 558-563.

23 Wang Y, Gu Y, Lewis DF. Endothelial angiotensin II generation induced by placenta-derived factors from preeclampsia. Reprod Sci 2008; 15: 932-938.

24 Lommerse T, Aardenburg R, Houben A, Peeters LL. Endothelium-dependent vasodilatation in formerly preeclamptic women correlates inversely with body mass index and varies independently of plasma volume. Reprod Sci 2007; 14: 765-770.

25 Ramsay JE, Jamieson N, Greer IA, Sattar N. Paradoxical elevationin adiponectin concentrations in women with preeclampsia. Hypertension 2003; 42: 891-894.

26 Haugen F, Ranheim T, Harsem NK, Lips E, Staff AC, Drevon CA. Increased plasma levels of adiponectin in preeclampsia: relationship to placanta and adipose tissue gene expression. Am J Physiol Endocrinol Metab 2006; 290: E326-E333.

$27 \mathrm{Li}$ LL, Kang XL, Ran XJ, Wang Y, Wang CH, Huang L, Ren J, Luo X, Mao XM. Associations between 45T/G polymorphism of the adiponectin gene and plasma adiponectin levels with type 2 diabetes. Clin Exp Pharmacol Physiol 2007; 34: 1287-1290.

28 Menzaghi C, Trischitta V, Doria A. Genetic influences of adiponectin on insulin resistance, type 2 diabetes, and cardiovascular disease. Diabetes 2007; 56: 1198-1209.

29 Iwashima Y, Katsuya T, Ishikawa K, Ouchi N, Ohishi M, Sugimoto K, Fu Y, Motone M, Yamamoto K, Matsuo A, Ohashi K, Kihara S, Funahashi T, Rakugi H, Matsuzawa Y, Ogihara T. Hypoadiponectinemia is an independent risk factor for hypertension. Hypertension 2004; 43: 1318-1323.

30 Bienertová-Vaskù J, Dostálová Z, Kanková K, Bienert P, Vaskù A, Unzeitig V. Is there any link between severe pre-eclampsia and defined polymorphisms in leptin and adiponectin genes? J Obstet Gynaecol Res 2008; 34: 858-864.

31 Hara K, Boutin P, Mori Y, Tobe K, Dina C, Yasuda K, Yamauchi T, Otabe S, Okada T, Eto K, Kadowaki H, Hagura R, Akanuma Y, Yazaki Y, Nagai R, Taniyama M, Matsubara K, Yoda M, Nakano Y, Tomita M, Kimura S, Ito C, Froguel P, Kadowaki T. Genetic variation in the gene encoding adiponectin is associated with an increased risk of type 2 diabetes in the Japanese population. Diabetes 2002; 51: 536-540.

32 Menzaghi C, Ercolino T, Salvemini L, Coco A, Kim SH, Fini G, Doria A, Trischitta V. Multigenic control of serum adiponectin levels: evidence for a role of the APM1 gene and a locus on 14q13. Physiol Genomics 2004; 19: 170-174. 